\title{
Quantitative Analysis of Microcystin-LR in Drinking Water Comparing On-Line Solid Phase Extraction and Direct Injection LC/MS/MS
}

\author{
R. MALARVILI, Y.Y. LOW AND A. ZAITON
}

\begin{abstract}
An efficient method for microcystin-LR in drinking water at the sub-ng/l level applying on-line solid phase extraction (SPE) with LC/MS/MS detection and comparing it to direct injection LC/ $\mathrm{MS} / \mathrm{MS}$ is presented. The performance of the method of direct injection did not significantly deviate from the SPE approach. However, the direct injection method used less sample volume $(100 \mu \mathrm{l})$ in shorter analysis time (4 min) and allowed more sample throughput. Conversely, the uncertainty of measurement could be reduced using SPE.
\end{abstract}

Key words: On-line solid phase extraction; direct injection; microcystin; LC/MS/MS

Microcystin (MC) is one of the most widespread cyanobacteria toxins found worldwide in inland and coastal water environments. They are produced by cyanobacteria (blue-green algae) that are found naturally in blooms of freshwater, lakes, streams, ponds, and other surface waters at favourable eutrophic, warm and low turbulent conditions. There are many types of MC; microcystin-LR (MC-LR) is one of the more toxic and well-studied varieties. Health effects of MC-LR can be acute or chronic and have been known to cause a tumour, liver and kidney damage potentially. The most severe consequence of exposure to $\mathrm{MC}$ is death. The impacts of chronic or acute exposure to MC-LR in humans, especially at the lower levels are more common via drinking water. There is also a particular concern for livestock (Fitzgerald \& Poppenga 1993; Kerr, McCoy \& Eaves 1987;
Moore \& Puschner 2012) and canine (Wood et al., 2010; DeVries, Galey, Namikoshi \& Woo 1993) exposure to MC via surface drinking water from contaminated lakes, ponds and rivers.

In response to continued harmful effects of MC-LR, the Ministry of Health Malaysia $(\mathrm{MOH})$ added MC-LR to its Contaminants List of unregulated contaminant and uses the Drinking Water Quality Surveillance Programme (KMAM) to monitor this pollutant in public water systems. The monitoring will provide $\mathrm{MOH}$ with nationally representative data on the occurrences of MC-LR in drinking water, which can support future regulatory determinations and other actions to protect public health. Under the KMAM programme, the sampling activities are carried out at water 
distribution system and three basic stations: water treatment intake; treatment plant outlet, and service reservoir outlet. The samples collected from these locations are monitored for MC-LR levels on a regular basis. The availability of rapid and low-cost assay is therefore essential to accommodate many routine MC analyses in water which uses no laborious technique.

Due to the increase of water sample testing demand, a high throughput analysis applying either on-line SPE or direct injection is essential to analyse a large number of samples quickly without using labourious manual SPE technique which may contribute to high variability in the analysis results.

In Malaysia, the maximum acceptable limit for MC-LR is set at $1 \mathrm{ng} / \mathrm{ml}$ by the National Standard Drinking water Quality which is also same with the World Health Organization recommended level of $1 \mathrm{ng} / \mathrm{ml}$ of MC-LR (free and cell bound) in drinking water for humans. Hence, an analytical method set-up which is robust and powerful for analysing drinking water contaminated with MC-LR at low levels is essential and needs to be in place. LC/MS/ MS analysis with electrospray ionization (ESI) was the method of choice for this study. The LC technique with MS/MS detector was preferred for the analysis of polar and thermally labile compounds mainly due to its selectivity and sensitivity, enabling efficient and reliable detection, and quantitation of MC-LR in drinking water.

Trace level analysis often adds to the challenge of direct determination of the compound of interest by chromatographic analysis, therefore demanding a sample preparation step that is often time consuming, tedious, and frequently overlooked. For a sensitivity analysis, an extraction and purification step are usually necessary. However, such analysis typically depends on the complexity of a sample. Here, the study compared the method performances of on-line solid phase extraction (SPE) and direct injection in determining MC-LR in drinking water. Online SPE injection method has the advantage of reducing sample preparation steps and enabling effective pre-concentration and clean-up of samples. Alternatively, direct injection method allowed high sample throughput and shorter analysis time.

\section{METHODOLOGY}

\section{Sample Preparation}

Internal standard (ISTD) solution, solution was added into water sample at $0.1 \mathrm{ng} / \mathrm{ml}$ concentration level. Then, the sample was filtered using $0.2 \mu \mathrm{m}$ nylon membrane filter, before extraction by on-line SPE and followed by UPLC-MS/MS analysis. The on-line SPE procedure consisted of three steps: loading; washing; and eluting the sample analyte through the SPE cartridge with the gradient flow of conditioning and rinsing. The extracts were then analysed by LC/MS/MS. The direct injection method only involved injecting of filtered water samples into LC/MS/MS for analysis with nil preparation. Data was acquired using electrospray ionization and multiple reaction monitoring (MRM) using one precursor ion/ two product ion transitions per compound (Table 1). 
Table 1. Instrument condition and MS/MS setting of on-line SPE method versus direct injection.

\begin{tabular}{|c|c|c|}
\hline $\begin{array}{l}\text { Description/ } \\
\text { Parameters }\end{array}$ & On-line SPE & Direct injection \\
\hline LC column & $\begin{array}{l}\text { Waters ACQUITY UPLC BEH C18 } \\
\text { Column, } 130 \AA, 1.7 \mu \mathrm{m}, 2.1 \mathrm{~mm} \times 100 \mathrm{~mm}\end{array}$ & $\begin{array}{l}\text { Waters ACQUITY UPLC } \\
\text { BEH C18 Column, } 130 \AA \text {, } \\
1.7 \mu \mathrm{m}, 2.1 \mathrm{~mm} \times 50 \mathrm{~mm}\end{array}$ \\
\hline SPE column & $\begin{array}{l}\text { Waters Oasis HLB Direct Connect HP } \\
\text { column, } 20 \mathrm{um}, 2.1 \mathrm{~mm} \times 30 \mathrm{~mm}\end{array}$ & - \\
\hline LC mobile phase & \multicolumn{2}{|c|}{ Deionised water and acetonitrile with $0.5 \%$ formic acid each. } \\
\hline Run time & $15 \mathrm{~min}$ & $4 \mathrm{~min}$ \\
\hline Injection volume & $1500 \mu 1$ & $100 \mu 1$ \\
\hline MS condition & \multicolumn{2}{|l|}{$\begin{array}{l}\text { Electrospray ionization (ESI) at positive m } \\
\text { Capillary voltage: } 0.5 \mathrm{kV} \\
\text { Source temperature: } 150^{\circ} \mathrm{C} \\
\text { Desolvation temperature: } 350^{\circ} \mathrm{C} \\
\text { Desolvation gas flow: } 650 \mathrm{~L} / \mathrm{hr} \\
\text { Collision gas flow: } 0.15 \mathrm{ml} / \mathrm{min}\end{array}$} \\
\hline $\begin{array}{l}\text { MRM setting } \\
\text { (m/z: mass-to- } \\
\text { charge; } C V \text { : } \\
\text { cone voltage; } \\
\text { CE: collision } \\
\text { energy) }\end{array}$ & $\begin{array}{ll}\text { MC-LR: } & \mathrm{m} / \mathrm{z}(995.7>135.05), \mathrm{CV} \\
& \mathrm{m} / \mathrm{z}(995.7>213.1), \mathrm{CV}: \\
\text { NOD (as ISTD): } & \mathrm{m} / \mathrm{z}(825.6>135.1), \mathrm{CV}:\end{array}$ & $\begin{array}{l}70 \mathrm{~V}, \mathrm{CE}: 70 \mathrm{eV} \\
0 \mathrm{~V}, \mathrm{CE}: 60 \mathrm{eV} \\
5 \mathrm{~V}, \mathrm{CE}: 60 \mathrm{eV}\end{array}$ \\
\hline
\end{tabular}

\section{Method Validation}

A sequence of water samples, blanks and controls samples were analysed using the described method. The obtained data were evaluated with a calibration for MC-LR. MCLR standards were prepared in deionised water over a range of $0.05 \mathrm{ng} / \mathrm{ml}$ to $10 \mathrm{ng} / \mathrm{ml}$ for online SPE and $0.1 \mathrm{ng} / \mathrm{ml}$ to $10 \mathrm{ng} / \mathrm{ml}$ for direct injection LC/MS/MS. Serial dilutions were obtained starting from $100 \mathrm{ng} / \mathrm{ml}$ concentration. The NOD ISTD was added to the standards and water samples at $0.1 \mathrm{ng} / \mathrm{ml}$ concentration.

For both methods, the LOD, signal-to-noise ratio $(3 \times \mathrm{SD}, \mathrm{n}=10$, signal-to-noise $>3: 1)$ and LOQ, $(10 \times$ LOD $)$ were determined. Precision and accuracy of the methods were evaluated with spiked samples of low concentrations.

\section{RESULTS AND DISCUSSION}

\section{On-line SPE Method}

The separation of the MC-LR was easier and distinct when using the on-line SPE method. Figure 1 presents a total ion chromatogram (TIC) with a chromatographic separation retention time ratio $\left(\mathrm{RT}_{\mathrm{MC}-\mathrm{LR}} / \mathrm{RT}_{\mathrm{NOD}}\right)$ of 1.04 . Selective detection was performed in MRM mode using two characteristic transitions for the compound. The ratio of both transitions (about 0.4) was used to confirm the presence of MC-LR in water. The calibration curve working 

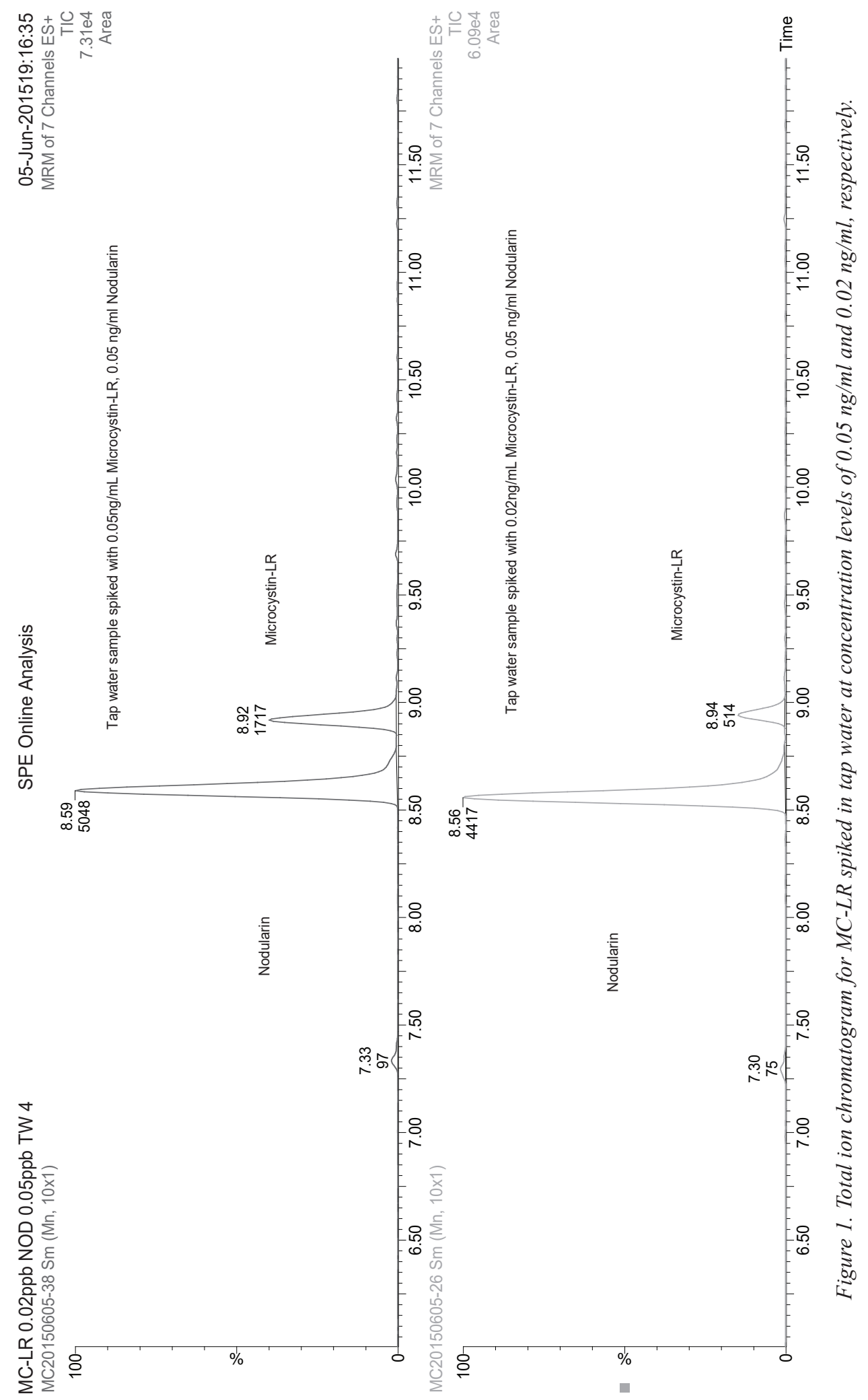
range of $0.05 \mathrm{ng} / \mathrm{ml}$ to $10.0 \mathrm{ng} / \mathrm{ml}$ is as presented in Figure 2. The calibration curve demonstrated a good linearity with correlation coefficient, $\mathrm{r}^{2} \geq 0.99$ and $\%$ deviation (\% residual) within the acceptable range of $\pm 20 \%$ from the actual value. The LOD and LOQ obtained were 0.005 and $0.05 \mathrm{ng} / \mathrm{ml}$. Good results were obtained for MC-LR fortified in tap water samples at $0.5 \mathrm{ng} /$ $\mathrm{ml}, 1 \mathrm{ng} / \mathrm{ml}$ and $1.5 \mathrm{ng} / \mathrm{ml}$, with recoveries $97 \%$,
$102 \%$ and $102 \%$, respectively (Table 2). The precision $(<5 \% \mathrm{RSD})$ was rather satisfactory with results $3.3 \%, 3.9 \%$ and $2.5 \%$ for MC-LR fortified in tap water samples at $0.05 \mathrm{ng} / \mathrm{ml}, 0.1$ $\mathrm{ng} / \mathrm{ml}$ and $1.0 \mathrm{ng} / \mathrm{mL}$, respectively (Table 2 ). The expanded combined relative uncertainty determined from the validation process was $10 \%$.

\section{Compund name: Microcystin-LR}

Correlation coefficient: $r=0.998274, r^{\wedge} 2=0.996552$

Calibration curve: $0.613313^{*} x+-0.0200707$

Response type: Internal Std (Ref 2), Area * (IS conc. / IS area)

Curve type: Linear, Origin: Exclude, Weighting: 1/x, Axis trans: None
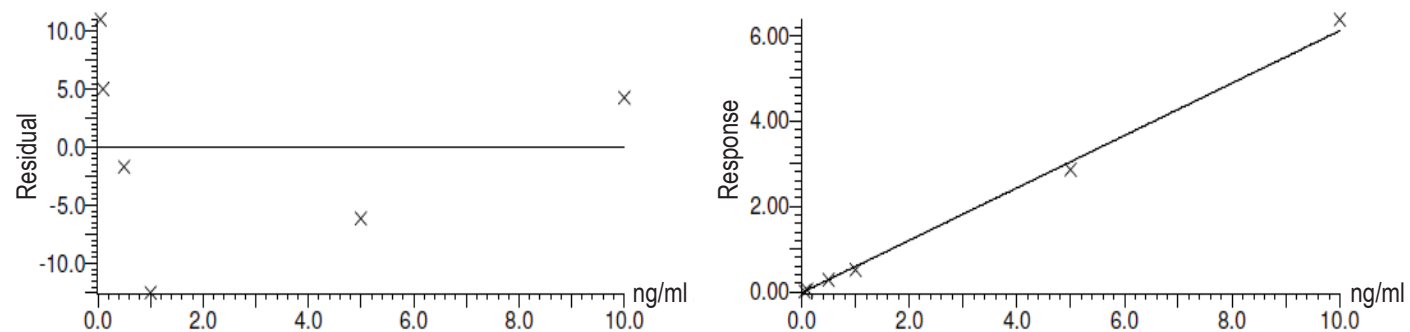

Figure 2. Calibration curve for $M C$-LR from $0.05 \mathrm{ng} / \mathrm{ml}$ to $10 \mathrm{ng} / \mathrm{ml}$.

Table 2. Comparison of results between on-line SPE method and direct injection.

\begin{tabular}{|c|c|c|}
\hline Description/ Parameters & Direct injection & Online SPE \\
\hline $\begin{array}{l}\text { Separation }\left(\mathrm{RT}_{\mathrm{MC}-\mathrm{LR}} /\right. \\
\left.\mathrm{RT}_{\mathrm{NOD}}\right)\end{array}$ & $2.26 / 1.61=1.40$ & $8.92 / 8.59=1.04$ \\
\hline $\begin{array}{l}\text { Linearity (internal standard } \\
\text { calibration) }\end{array}$ & $0.1-10 \mathrm{ng} / \mathrm{ml}\left(\mathrm{r}^{2} \geq 0.99\right)$ & $0.05-10 \mathrm{ng} / \mathrm{ml}\left(\mathrm{r}^{2} \geq 0.99\right)$ \\
\hline $\begin{array}{l}\mathrm{LOD}=3 \times \mathrm{SD} \\
(\text { In tap water) }\end{array}$ & $0.0192 \mathrm{ng} / \mathrm{ml}$ & $0.0050 \mathrm{ng} / \mathrm{ml}$ \\
\hline $\begin{array}{l}\mathrm{LOQ}=10 \times \mathrm{LOD} \\
(\text { In tap water })\end{array}$ & $0.0959 \mathrm{ng} / \mathrm{ml}$ & $0.0501 \mathrm{ng} / \mathrm{ml}$ \\
\hline Precision (\% RSD) & $0.5 \mathrm{ng} / \mathrm{ml}: 5 \%(\mathrm{n}=10)$ & $0.05 \mathrm{ng} / \mathrm{ml}: 3.3 \%(\mathrm{n}=10)$ \\
\hline (In tap water) & $0.1 \mathrm{ng} / \mathrm{ml}: 4 \%(\mathrm{n}=10)$ & $0.1 \mathrm{ng} / \mathrm{ml}: 3.9 \%(\mathrm{n}=10)$ \\
\hline \multirow{4}{*}{$\begin{array}{l}\text { Relative recovery }(\%) \\
\text { (In tap water) }\end{array}$} & $1 \mathrm{ng} / \mathrm{ml}: 17 \%(\mathrm{n}=30)$ & $1 \mathrm{ng} / \mathrm{ml}: 2.5 \%(\mathrm{n}=20)$ \\
\hline & $0.1 \mathrm{ng} / \mathrm{ml}: 119 \%(\mathrm{n}=20)$ & $0.5 \mathrm{ng} / \mathrm{ml}: 97 \%(\mathrm{n}=10)$ \\
\hline & $1 \mathrm{ng} / \mathrm{ml}: 106 \%(\mathrm{n}=10)$ & $1 \mathrm{ng} / \mathrm{ml}: 102 \%(\mathrm{n}=10)$ \\
\hline & & $1.5 \mathrm{ng} / \mathrm{ml}: 102 \%(\mathrm{n}=10)$ \\
\hline $\begin{array}{l}\text { Expanded combined relative } \\
\text { uncertainty }\left(\mathrm{U}_{\mathrm{cr}}\right)\end{array}$ & $19 \%$ & $10 \%$ \\
\hline
\end{tabular}




\section{Direct Injection Method}

The analysis time of direct injection method was only 4 min with a chromatographic separation retention time ratio of 1.40 (Figure 3). This allows high throughput sample analysis. Calibration curve for the range, 0.1 to $10.0 \mathrm{ng} / \mathrm{ml}$ displayed a good linearity with correlation coefficient, $\mathrm{r}^{2} \geq 0.99$ and $\pm 20 \%$ deviation (Figure 4 ). The LOD and LOQ determined were $0.019 \mathrm{ng} / \mathrm{ml}$ and $0.096 \mathrm{ng} / \mathrm{ml}$, respectively. The recovery results of MC-LR fortified in tap water samples (Table 2) at $0.1 \mathrm{ng} / \mathrm{ml}$ and $1 \mathrm{ng} / \mathrm{ml}$ were $119 \%$ and $106 \%$. Precision results were acceptable with $<20 \%$ RSD determined as $5 \%, 4 \%$ and $17 \%$ for MC-LR fortified in tap water samples at 0.5 $\mathrm{ng} / \mathrm{ml}, 0.1 \mathrm{ng} / \mathrm{ml}$ and $1.0 \mathrm{ng} / \mathrm{ml}$ respectively (Table 2). The expanded combined relative uncertainty determined from the validation process was $19 \%$.

\section{Comparison between Two Methods}

The validation data showed that the direct injection method did not significantly deviate from the on-line SPE method. The LOD and LOQ obtained for both methods were well below than the NSDWQ standard requirements of $1 \mathrm{ng} / \mathrm{ml}$. The slightly improved sensitivity for on-line SPE method could be explained by a lower LOD and LOQ than direct injection method due to injection of larger sample volume $(1500 \mu \mathrm{l})$ compared with $100 \mu \mathrm{l}$ for direct injection. Large sample volume injection was able using on-line SPE due to concentration enrichment of analyte in the SPE cartridge, thus enchase its sensitivity. However, the analysis time of on-line SPE method was much longer (15 min) compared with direct injection (4 min) as longer gradient flow time was required for multi-steps of conditioning, loading, washing, and elution. The recovery results obtained for both methods were considered acceptable as they fall within the range of $70 \%$ to $120 \%$ [6].

Both LC-MS/MS methods were also compared using statistical significance tests. The F-test was applied to determine the precision variability between the two methods, while the $t$-test was applied to determine if there was a significant difference between these methods. The calculated F-value, 0.03 and $t$-value, 0.22 , were below the critical values of 2.42 and 2.01 , respectively at $95 \%$ confidence level. Although measurement uncertainty for on-line SPE method was found to be almost two times lower than direct injection, the significance tests outcomes indicated that there were no significant differences between these methods.

\section{CONCLUSION}

On the whole, all validation results of both methods fall within the acceptable limits that complied with EU Commission Decision 2002/657/EC (Anon. 2002) and EURACHEM (Anon. 2014) guidelines requirements. Also, the statistical data proved that the two methods were equally precise and there was no significant difference between these methods. Both methods were rather simple, rapid, precise, accurate and sensitive and could be deployed for routine analysis. However, the advantage of direct injection over on-line SPE method was the former which used smaller sample volume $(100 \mu \mathrm{l})$ and shorter analysis time (4 min) thus enabled high sample throughput.

Date of receipt: November 2017 Date of acceptance: December 2017 

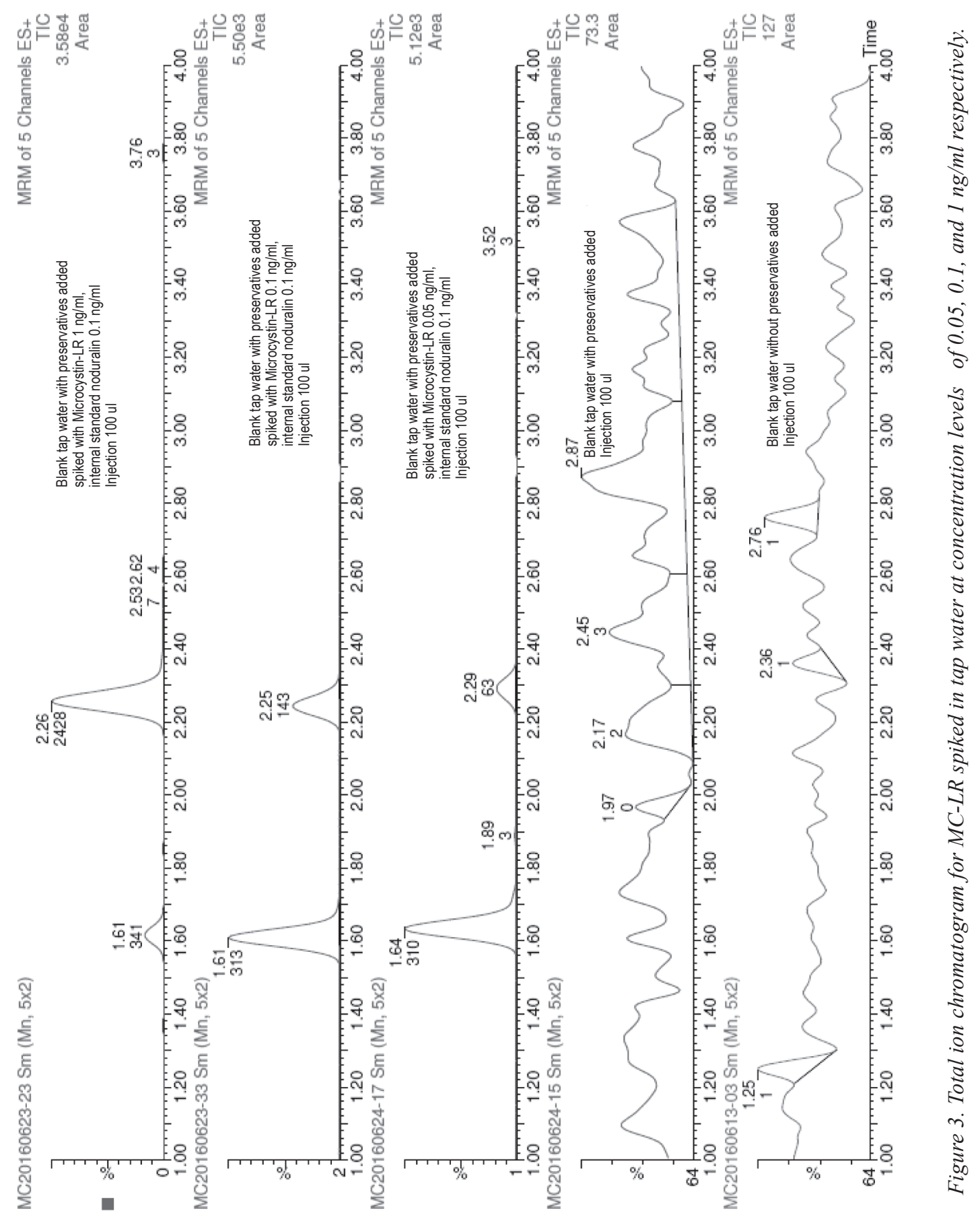
Compund name: Microcystin-LR

Correlation coefficient: $r=0.998658, r^{\wedge} 2=0.997319$

Calibration curve: 0.405756 * $x+-0.00651749$

Response type: Internal Std (Ref 2), Area * (IS conc. / IS area)

Curve type: Linear, Origin: Exclude, Weighting: 1/x, Axis trans: None
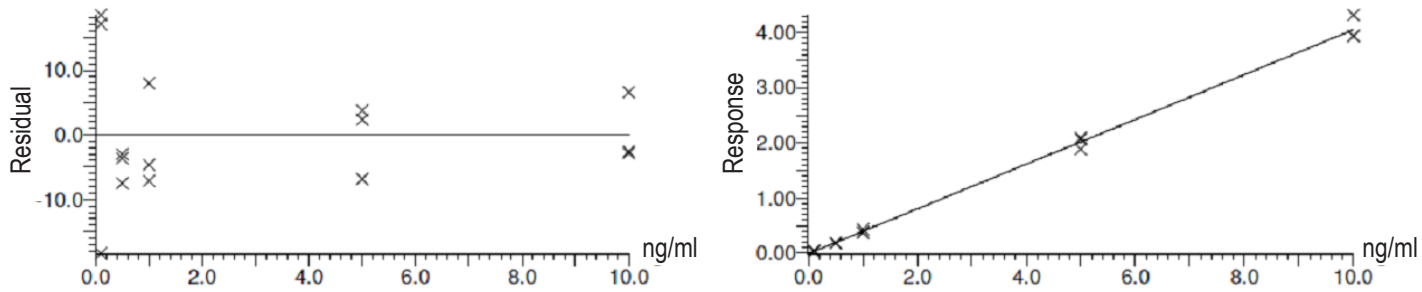

Figure 4. Calibration curve for Microcystin-LR from $0.1 \mathrm{ng} / \mathrm{ml}$ to $10 \mathrm{ng} / \mathrm{ml}$.

\section{REFERENCES}

Anonymous 2002, Commission decision 2002/657/EC, implementing council directive 96/23/EC concerning the performance of analytical methods and the interpretation of results.

Anonymous 2014, Eurachem guide, the fitness for purpose of analytical methods $-a$ laboratory guide to method validation and related topics.

DeVries, SE, Galey, FD, Namikoshi, M \& Woo, JC 1993, 'Clinical and pathologic findings of blue-green algae (Microcystis aeruginosa) intoxication in a dog', Journal of Veterinary Diagnostic Investigation, vol. 5, pp. 403-408.

Fitzgerald, SD \& Poppenga, RH 1993, 'Toxicosis due to microcystin hepatotoxins in three Holstein heifers', Journal of Veterinary Diagnostic Investigation, vol. 5, pp. 651-653.

Kerr, LA, McCoy, CP \& Eaves, D 1987, 'Bluegreen algae toxicosis in five dairy cows', $J$. American Veterinary Medical Association, vol. 191, pp. 829-830. [PubMed]

Moore, CE \& Puschner, B 2012, 'Cyanobacteria', in Small animal toxicology, 3rd edn, Chap 44, Saunders, Philadelphia, PA, USA.

Wood, SA, Heath, MW, Holland, PT, Munday, R, McGregor, GB \& Ryan, KG 2010, 'Identification of a benthic microcystinproducing filamentous cyanobacterium (Oscillatoriales) associated with a dog poisoning in New Zealand', Toxicon, vol. 55, pp. 897-903. [PubMed] 